\title{
Budget an endless bone of contention
}

\section{Brussels}

BY the standards of many governments which are members of the EEC, the Commission has a substantial budget for research. In the five-year period ending with 1991, the Commission will have been spending roughly 1,500 million ECU a year, but the research people at Brussels are now excited by the prospect that their collective budget will be increased to 2,500 million ECU a year from about now.

Even at the present level of spending, the Commission's research budget is, in round numbers, virtually on a par with what Britain calls its Science Budget, spent through the research councils on university and in-house basic research. It is also roughly equivalent to the combined federal subventions in West Germany of the Max-Planck Gesellschaft and the Deutsche Forschungsgemeinschaft. But officials here insist that their budget is roughly 4 per cent only of total European spending on research.

The prospect that there will now be an increase seems to be a little-noticed consequence of the budget agreement in the closing days of 1988 at which member governments agreed that there should be a further squeeze on the cost of supporting European agriculture. As yet, there are no firm plans for spending the extra money. (There are a few suggestions elsewhere in this section of Nature.)

This is a far cry from the second half of 1986 , when it seemed as if the British government would carry its opposition even to a reduced programme to extreme lengths. Earlier that year, the British and West German governments had objected both to the scale and the character of what the Commission calls its "framework" programme. Even after the West German position had been modified, the British government persisted with its opposition, acquiescing only after 1988 had begun.

Curiously, direct authority for the Commission's research programme derives only from the Single Act signed in February 1986, which leaves the Commission in no doubt of its responsibilities. The chief task is to strengthen European industry and to help make it more competitive. Roughly 42 per cent of spending in the current programme is under the heading of "Towards a large market", most of it in telecommunications, but 100 million ECU is set aside for traffic and travel projects. Energy ( 22 per cent), industrial modernization (16 per cent) and applied biology ( 5 per cent) consume a little more than that (see figure).

The general way of working in the industrial field is that the Commission offers research and development grants on a
50:50 matching basis to consortia of industrial companies or other organizations (such as universities and national government laboratories). A precondition of an award is that the partners must be drawn from at least two European countries. The best-known of these programmes is the telecommunications programme, ESPRIT, on which 2,350 million ECU will have been spent between 1986 and the closing months of 1992.

But the Commission also has research projects which are more particularly its own, outstanding among which is the controlled (and high-temperature) thermonuclear fusion programme whose chief embodiment is the JET (for Joint European Torus) thermonuclear tokamak device in Oxfordshire, England. This pro-

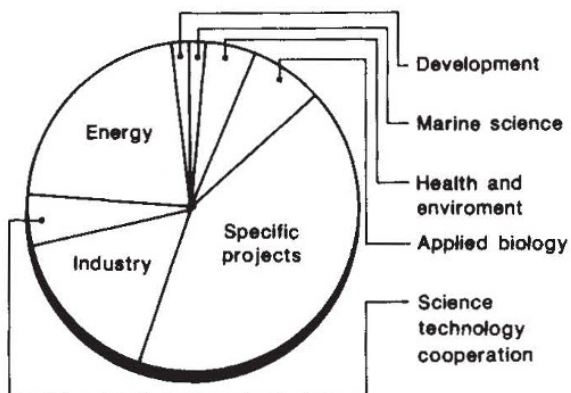

The Commission's current research spending. gramme will have cost the EEC more than 1,200 million ECU over six years by the time the present phase comes to an end in 1991. (The Commission meets 80 per cent of the total cost.) The design of the next machine, called NET (for Next European Torus) is under way but a decision on its construction (and even siting) has yet to be made. The Commission also contributes to the cost of some national thermonuclear programmes as at Garching (West Germany) and Frascati (Italy).

More contentiously under the Commission's own control are the laboratories grouped together under the name Joint Research Centre (see page 732), mostly inherited from the Euratom organization (which, like the European Iron and Steel Community, was one of the precursors of the EEC). There are four laboratories in Belgium (Geel), Italy (Ispra), the Netherlands (Petten) and West Germany (Karlsruhe), but the work is organized into nine divisions (called institutes), dealing with topics as different as transuranic elements (Karlsruhe), materials (Petten) and environmental safety (Ispra).

The centre's budget problems have their roots in EEC history. Euratom was conceived of as a research organization, but later acquired responsibility for the operation within Europe of safeguards on the use of fissile materials. When Eur- atom's member states were full of enthusiasm for nuclear energy, it seemed natural that the organization should be ready to build prototype reactors of all kinds, for which purpose research stations were plainly needed. But then the gilt disappeared from that gingerbread.

Ispra, the largest site, has been consistently the most troublesome. Now, after successive painful reorganizations, the laboratory is on the way to being a kind of European Standards Laboratory with responsibilities, on the side, for nuclear reactor safety and environmental safety issues. But the Commission's continued support of the Joint Research Centre was one of the causes of trouble in 1986.

By the standards of these expenditures, basic research comes a poor last (page 734). Spending on the relevant part of what is called the EEC's stimulation programme has been fixed at 167 million ECU over the five years to the end of 1992 (up from a total of 60 million ECU in the previous three-year period). Transnational collaboration is a precondition for a successful application, but matching funds are not required.

On the face of things in Brussels, there is general contentment with this pattern of spending. The common goal is to create the single market and somehow to arrange that it is competitive with the rest of the world. If there is a research programme, and especially a substantial one, is it not self-evident that it should be pointed in the same direction?

To outsiders, that logic may not be nearly as compelling. If, for example, the objective of the creation of the single market is that competition between companies should be free and efficient, without reference to their geographical location, will it continue to make sense that most forms of EEC research support should be devised so as to marry efficient companies with less efficient collaborators? And if the Community is concerned about its supply of skilled manpower, might there not be something to be said for strengthening the infrastructure?

Asking such questions in Brussels does not physically endanger one's person; indeed, people are very polite and are willing to acknowledge that they are questions that should be asked. But of whom? The Commission has problems enough on its mind, the European Parliament is preoccupied with the environment and bothered by the discomforts the single market will bring to its constituents. The main council (which meets only twice a year) will have horrendous political disagreements, such as that over monetary union, to resolve by 1992 , while the subcouncil on research could hardly settle on a change of direction without approval from above. Yet it will be a pity for Europe's dreams to go unanswered because nobody has the time to listen to them. 